University of Nebraska - Lincoln

DigitalCommons@University of Nebraska - Lincoln

8-1997

\title{
Evolutionary Constraints on Population Structure: The Parasites of Fundulus zebrinus (Pisces: Cyprinodontidae) in the South Platte River of Nebraska
}

John J. Janovy Jr.

University of Nebraska - Lincoln, jjanovy1@unl.edu

Scott D. Snyder

University of Nebraska at Omaha, sdsnyder@mail.unomaha.edu

Richard E. Clopton

Peru State College, RClopton@peru.edu

Follow this and additional works at: https://digitalcommons.unl.edu/bioscijanovy

Part of the Parasitology Commons

Janovy, John J. Jr.; Snyder, Scott D.; and Clopton, Richard E., "Evolutionary Constraints on Population Structure: The Parasites of Fundulus zebrinus (Pisces: Cyprinodontidae) in the South Platte River of Nebraska" (1997). John Janovy Publications. 37.

https://digitalcommons.unl.edu/bioscijanovy/37

This Article is brought to you for free and open access by the Papers in the Biological Sciences at DigitalCommons@University of Nebraska - Lincoln. It has been accepted for inclusion in John Janovy Publications by an authorized administrator of DigitalCommons@University of Nebraska - Lincoln. 


\title{
EVOLUTIONARY CONSTRAINTS ON POPULATION STRUCTURE: THE PARASITES OF FUNDULUS ZEBRINUS (PISCES: CYPRINODONTIDAE) IN THE SOUTH PLATTE RIVER OF NEBRASKA
}

\author{
J. Janovy, Jr., S. D. Snyder, and R. E. Clopton \\ School of Biological Sciences, University of Nebraska-Lincoln, Lincoln, Nebraska 68588-0118
}

\begin{abstract}
Population and community descriptor values (parasites per host, prevalence per parasite species, variance/mean ratios, species density, and diversity indices) for the 7-species parasite community of 61 relatively homogeneous samples of Fundulus zebrinus (Pisces: Cyprinodontidae) in the South Platte River of Nebraska, U.S.A., taken over a 14-yr period, are reported. South Platte River streamflow fluctuates over 2 orders of magnitude on several time scales-monthly, annually, and over multiple year wet-dry cycles. Relatively homogeneous sampling of a single host species with several parasite species provided a system that allowed assessment of the contribution of evolved parasite life cycles to population structure in an everchanging environment. No significant negative species-to-species associations were observed. Species abundance, order of abundance, and diversity were affected most strongly by streamflow, with high water reducing prevalence and abundance of larval trematode parasites. Each parasite species had its characteristic long- and short-term patterns of variation in population descriptor values, with mostly longterm stability superimposed on sometimes extreme short-term fluctuations of descriptor values. The differences in these characteristic patterns were considered products primarily of the evolved life cycle traits and transmission mechanisms operating in the common fluctuating environment. The parasite community as a whole showed resilience, returning to preperturbation diversity following extended periods of high water.
\end{abstract}

The Platte River system of Nebraska provides a natural laboratory in which abundant populations of small fish acquire various kinds of parasites under fluctuating transmission conditions. The South Platte River (headwaters in the Rocky Mountains west of Denver, Colorado) is particularly useful as a site for long-term studies of parasite population and community dynamics because streamflow, the primary factor influencing aquatic habitat diversity in the bed and channels, varies by up to 2 orders of magnitude. Furthermore, South Platte River streamflow is not regulated by dams and diversions to the same extent as other prairie rivers, e.g., the North Platte. Annual average South Platte River flow thus is determined mainly by Rocky Mountain snowpack, seasonal flow is melt dependent, and headwater storms can produce temporary surges in discharge. Streamflow fluctuations therefore occur on a number of time scales, from rapid responses to headwater events to multiyear dry-wet cycles.

The Platte River system contains about 40 species of fish, at least half of which are minnows, but the cyprinodontid Fundulus zebrinus is abundant, widely distributed throughout the system, and infected with at least 7 different species or ecotypes of parasites (Janovy and Hardin, 1987, 1988). Parasite transmission is potentially affected by abiotic conditions, both directly, e.g., through concentration of hosts or changes in the current through which infective stages must pass, and indirectly, mainly through effects on intermediate host populations (Webbe, 1966a, 1966b; Camp and Huizinga, 1980; Granath and Esch, 1983a, 1983b; Stables and Chappell, 1986). The fish population can be considered a supply of patches that vary genetically and physiologically only within the limits of the host species and are colonized in ecological time by parasites that, in turn, are constrained by their evolved life cycle requirements (Dobson and Pacala, 1992). Among the parasite species are extreme specialists (the gill-inhabiting monogenean Salsuginus thalkeni, found only on F. zebrinus) and extreme generalists (larval Posthodiplostomum minimum, occurring in the eyes and body cav-

Received 24 June 1996; revised 19 February 1997; accepted 19 February 1997. ity, and reported from nearly 100 species of fish). These parasites also are transmitted through several different types of life cycles (Table I) and thus represent a variety of transmission mechanisms and potential responses to fluctuating abiotic conditions. At its most general level, the study of $F$. zebrinus parasite population and community dynamics is a study of the response of evolutionarily constrained parasite transmission systems (life cycles) to everchanging, and only partially predictable, transmission conditions. Finally, the entire system is easily modelled, leading to testable predictions, about such responses, applicable to natural systems more easily manipulated than the South Platte River and its inhabitants (Janovy and Kutish, 1988; Janovy et al., 1990, 1992, 1995).

It is hypothesized that evolved parasite life cycles and the associated transmission mechanisms are major contributors to parasite species differences in population structure, especially over the long term. As a consequence of such contributions, these life cycles represent constraints against which the shorter, ecological time, transmission events operate. Thus, an observed parasite population structure (prevalence, mean, variance/mean ratio, frequency distribution of best fit, etc.) has both evolutionary and ecological components. The evolutionary component is held constant in ecological time by parasite genes, whereas the ecological component can be varied either experimentally or by nature. Such variation in the ecological component should reveal the contribution of the evolutionary component, which should be manifested as taxon-specific population structure responses to the varying, but shared, transmission conditions.

The objective of the studies described in this paper was to assess the validity of the above ideas by determining the characteristic responses of several parasite species' population structures to fluctuating transmission environments over a relatively long period. When this project was initiated in the late 1970s it was felt that $5 \mathrm{yr}$ was an adequate time to gather data (Janovy and Hardin, 1987, 1988). The subsequent 9 yr, however, provided data on processess not revealed by the earlier observations, e.g., evidence for overwinter mortality of fish infected with larval trematodes and the effects of sustained low 
TABLE I. Parasites, with life cycles and transmission mechanisms, of Fundulus zebrinus in the South Platte River of Nebraska.

Parasite; infection site; life cycle; intermediate host; transmission stages

Myxobolus funduli (Myxozoa); gill tissues; indirect; freshwater oligochaetes?; spore-bearing triactinomyxons

Trichodina sp. (Ciliophora); gill surface; direct; swimming telotroch stage

Gyrodactylus bulbacanthus (Monogenea); gill surface; direct; viviparous, fish-to-fish contact and passing of juvenile worms

Salsuginus thalkeni (Monogenea); gill surface; direct; egg, free-swimming larva encounters host

Gyrodactylus stableri (Monogenea); body surface, fins; direct; viviparous, fish-to-fish contact and passing of juvenile worms

Posthodiplostomum minimum (Digenea, larva); within eyes; indirect; snails; free-swimming cercariae penetrate fish

$P$. minimum (Digenea, larva); within body cavity; indirect; snails; free-swimming cercariae penetrate fish

water on the various parasites population structures (see below). The following specific questions were derived from the hypothesis above: (1) Are parasite population and community structures stable over relatively long periods? And (2), do the various parasite species respond differently to changing transmission conditions (responses being measured as changes in population structures)?

\section{MATERIALS AND METHODS}

Parasite population and community terminology is derived from Margolis et al. (1982) and Esch et al. (1990), except that the word mean, instead of relative density, is used for the mathematical mean of a frequency distribution. Population descriptors used in this study were: infrapopulation (number of parasites in an individual host), prevalence (percentage or decimal fraction of hosts infected), mean (average number of parasites per host in a sample), and variance/mean ratios (infrapopulations as variates), the latter as indicators of the degree of parasite population aggregation (Taylor et al., 1978, 1979). Community level descriptors were: infracommunity diversity $\left(\mathrm{H}^{\prime} \mathrm{IC}=\right.$ Shannon's $\mathrm{H}^{\prime}$ for all parasites of all species in an individual host), mean Shannon's $\mathbf{H}^{\prime}$ for all infracommunities in a sample (mean $\left.H^{\prime} I C\right)$, Shannon's $H^{\prime}$ for the combined parasites in a fish sample $\left(\mathrm{H}^{\prime} \mathrm{SC}\right)$, species density (mean of frequency distribution generated by plotting number of hosts in a sample against parasite species/host classes; see Janovy et al., 1995), and mean prevalence (of the 7 parasite species or ecotypes).

All collections were made between May and October using a 0.63$\mathrm{cm}^{2}$ mesh seine. Collection site, fish collection and examination methods, and data analysis were as described previously (Janovy and Hardin, 1987, 1988; Janovy and Kutish, 1988; Janovy et al., 1992, 1995). Collections were made from the South Platte River $4.8 \mathrm{~km}$ east of Roscoe, Keith County, Nebraska. For spring and summer collections, fish from a single trip to the river, typically taking no more than $1 \mathrm{hr}$, were taken to the Cedar Point Biological Station, $13 \mathrm{~km}$ north of Ogallala, Keith County, Nebraska, transferred to an aquarium, and dissected within 72 $\mathrm{hr}$ of capture. Five fall collections, made after September 1, were taken to the University of Nebraska-Lincoln for processing; fish were aerated and cooled with ice for the 5-hr trip and again processed within $72 \mathrm{hr}$ of capture. These collection conditions satisfy the homogeneity requirements for parasite field data sets for each sample (Janovy et al., 1992). Cohorts are obviously lumped in such collections, but seine mesh size selects fish mostly $3.5 \mathrm{~cm}$ and larger, i.e., older young of the year (6$8 \mathrm{wk}$ posthatching), second-, and third-year fish. Samples consisted primarily of second-year fish as estimated by size (mean total length = $6.21 \mathrm{~cm}$, variance $=0.95 \mathrm{~cm}, n=1,219 ;$ males $=6.32$, var $=0.97, n$ $=595$; females $=6.10$, var $=0.91 ; n=624$; cf. Minckley and Klaassen, 1969; Brown, 1986). Each fish was measured (total length) and its sex determined, occasionally during dissection if not obvious from external characters. Body surface, eyes, gills (including both sides of each arch), intestine, and body cavity were examined for parasites, and numbers of the various species were recorded for each infection site. $M y x$ obolus funduli cysts were recorded as immature or mature (translucent or opaque), and $S$. thalkeni were recorded as immature, mature, or gravid, but all individual parasites are included in the numbers reported in this paper.

The data set consists of parasite counts per fish, per parasite species, from 61 relatively homogeneous samples of 8-24 fish each (total 1,219), taken from 1982 to 1995 . Actual collection dates (number of fish examined) are as follows: 1982 : $5 / 20(16), 7 / 19(16), 8 / 2(26) ; 1983: 6 / 9$ (21), 6/15 (11), 7/14 (16), 7/25 (28); 1984: 6/1 (19), 6/19 (15), 7/25 (8); 1985: 5/20 (23), 5/25 (27), 6/8 (24), 6/15 (24), 6/27 (19), 6/29 (23), $7 / 1$ (22), 7/20 (23), 8/10 (19); 1986: 5/21 (24), 6/4 (24), 6/29 (24), 7/16 (14); 1987: 5/26 (24), 6/12 (20), 7/30 (22), 9/8 (24); 1988: 5/11 (16), 6/1 (24), 6/19 (24), 7/10 (20), 8/9 (20), 10/11 (18); 1989: 5/22 (24), $6 / 22(24), 7 / 26(19), 9 / 2(20), 10 / 5$ (8); 1990: 5/16 (24), 6/17 (20), 7/14 (16), 8/4 (20); 1991: 5/29 (24), 6/21 (16), 7/19 (17), 9/29 (20); 1992: $5 / 5$ (21), 6/12 (24), 7/7 (20), 8/18 (12); 1993: 5/14 (24), 6/17 (24), 7/31 (22); 1994: 5/15 (20), 6/19 (20), 7/17 (16), 9/17 (16); 1995: 5/15 (15), $6 / 18(20), 7 / 22$ (11), 8/27 (24).

Streamflow records were obtained from the State of Nebraska Department of Water Resources for gauging station 06765500, the South Platte River at North Platte, Nebraska, the station nearest the collecting site for which complete daily records were available. The data presented in this paper include those previously published for the years 19821986, as well as new observations from 1987 to 1995 ; the latter years include an extended period of low streamflow and a single short-term event of very high streamflow (1995), whereas the earlier years included an extended period of relatively high streamflow (Figs. 1-3). Mean annual daily streamflow is the average, over a water year (October 1September 30, Fig. 1), of the daily discharge measured in cubic feet per sec (units used by Department of Water Resources; $1 / \mathrm{sec}=\mathrm{ft}^{3} / \mathrm{sec}$ $\times 28.319$ ) at a particular gauging station.

The null hypotheses of no associations between parasites species and the null hypothesis of no relationships between abundance rank, community diversity descriptor values, and streamflow were tested using correlations with Bonferroni corrections for pairwise comparisons (Silverton and Wilson, 1994). The null hypothesis of no differences between mean $\mathrm{H}^{\prime} \mathrm{IC}$ and $\mathrm{H}^{\prime} \mathrm{SC}$ was tested using paired- $t$. Species density distributions were tested against the multiple-kind lottery null model (tests for detectable associations regardless of origin) of Janovy et al. (1995). The null hypothesis of no relationship between parasite burdens in fall fish and those in spring fish was tested using correlations between mean parasites per host in the first collection of a year and the last collection of a previous year as variates in order to assess potential parasite effects on overwintering hosts. Stability of parasite population structure was assessed using correlations between sample means and prevalences for each parasite, concurrent water year streamflow, prior year streamflow, and year of study. Calculations were performed using FieldStat (Clopton and Janovy, 1991).

Posthodiplostomum minimum in the eye was considered a different ecotype from larvae of the same species in the body cavity because of the potential difference in effects on host biology of parasites embedded in the retina vs. those in the body cavity.

Conclusions regarding the effect of the South Platte River streamflow on physid snail populations are based on unpublished natural historytype observations resulting from approximately 500 field trips to various South Platte sites over the 22-yr period from 1975 through 1996. Very large snail populations occur during extended periods when low water is combined with a relatively warm spring, and several thousand snails can be collected easily from pools during a 1-hr trip to the river throughout the field season. In high-water periods, these pools are obliterated, often inundated by water several meters deep, with a strong current (the "scouring" floods that clear woody vegetation from the stream bed). In high streamflow periods, fish can usually be collected in refugia, including temporary channels in pastures and bottomland woods adjacent to the river. Snails, however, become quite rare under these conditions, presumably being washed downstream, and do not appear again in sizeable numbers in the main channel pools for several weeks following flood periods. If flooding continues through the summer, e.g., as in 1983 and 1984, both migratory bird (definitive hosts for $P$. minimum) use 

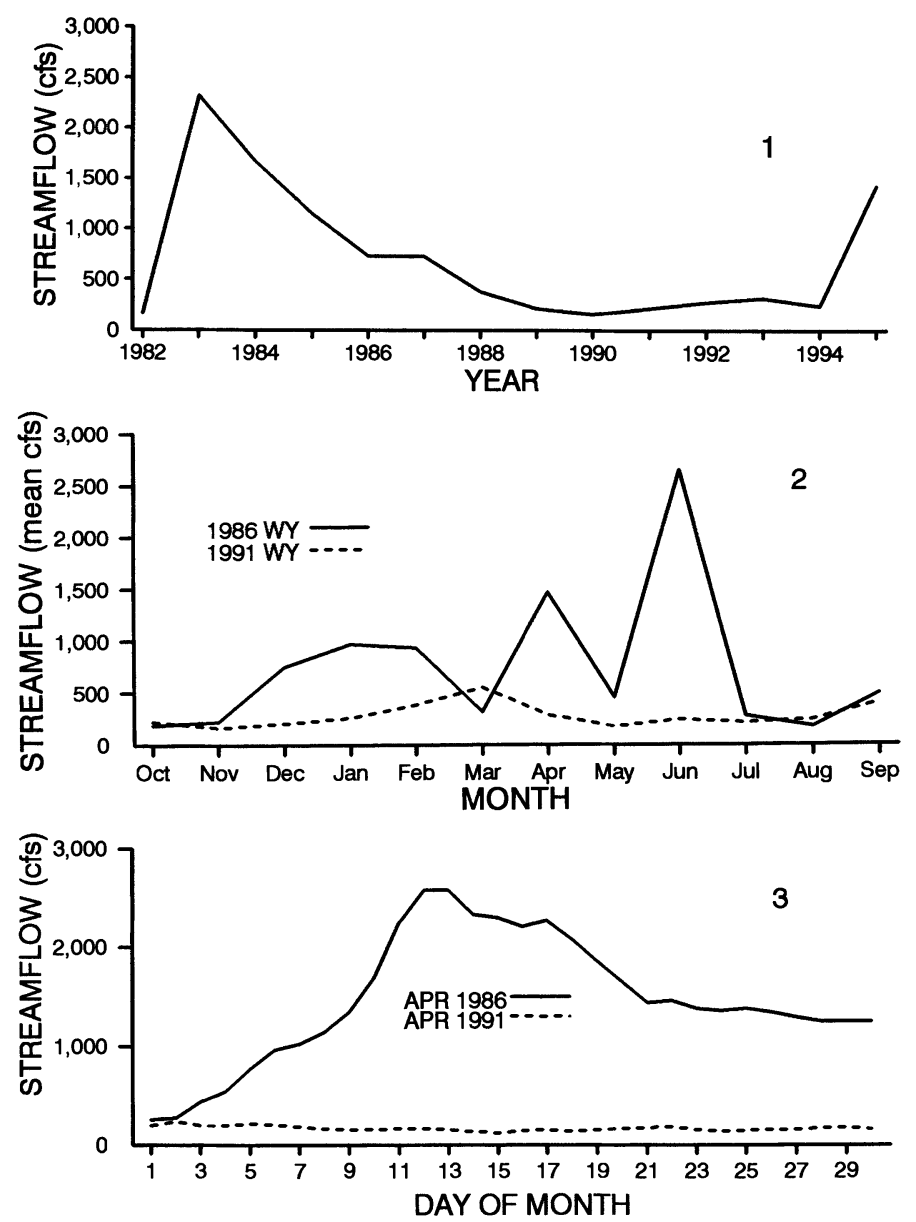

FIGURES 1-3. Streamflows, expressed as cubic feet per sec (1/sec = $\left.\mathrm{ft}^{3} / \mathrm{sec} \times 28.319\right)$, in the South Platte River at North Platte, Nebraska. 1. Mean daily streamflows per year for the years 1982-1995, illustrating long-term fluctuations in fish parasite transmission conditions. Ordinate values are the sum of all daily streamflow rate measurements divided by 365. 2. Mean daily streamflows per month for the 1986 and 1991 water years, illustrating within-year differences in flow rates between water years. 3. Daily streamflows for April 1986 and April 1991, illustrating short-term fluctuation differences in parasite transmission conditions between years.

and snail populations remain low, the latter through the following spring and early summer. Channel pool snail populations are presumably reestablished from populations in wet meadows, irrigation ditches, or small tributaries, in addition to the expected transportation into a braided prairie river from various sites of snails or eggs on birds, beaver, muskrats, etc.

\section{RESULTS}

Figure 1 shows mean annual daily flow for water years 1982 through 1995 and illustrates the nature of large scale streamflow fluctuations. Figure 2 shows the monthly mean daily flow for $2 \mathrm{yr}, 1986$ and 1991, and illustrates the nature of shorter term streamflow fluctuations typical of relatively high-water, vs. lowwater, years. Figure 3 shows the daily discharge for April 1986, and April 1991 and illustrates the shortest term streamflow fluctuations measured. The 3 figures together demonstrate the forms and scales of fluctuation in abiotic conditions in the South Platte River, i.e., those conditions under which parasite transmission must occur if the parasite species are not to become locally
TABLE II. Between-parasite species infrapopulation correlations; $\mathrm{n}=$ 1,219 fish taken from 1982 through 1995

\begin{tabular}{|c|c|c|c|c|c|c|c|}
\hline $\begin{array}{l}\text { Parasite } \\
\text { species }\end{array}$ & $\mathrm{MF}^{*}$ & TR & GB & ST & GS & PM-E & PM-BC \\
\hline MF & 1 & 0.08 & 0.01 & 0.07 & 0.01 & -0.05 & -0.03 \\
\hline TR & & 1 & 0.08 & 0.03 & 0.20 & 0.02 & 0.10 \\
\hline GB & & & 1 & -0.01 & 0.61 & 0.02 & 0.01 \\
\hline ST & & & & 1 & 0.04 & 0.15 & 0.18 \\
\hline GS & & & & & 1 & 0.08 & 0.08 \\
\hline PM-E & & & & & & 1 & 0.85 \\
\hline PM-BC & & & & & & & 1 \\
\hline
\end{tabular}

* Abbreviations: $\mathrm{MF}=$ Myxobolus funduli $; \mathrm{TR}=$ Trichodina $\mathrm{sp} ; \mathrm{GB}=$ Gyro dactylus bulbacanthus; $\mathrm{ST}=$ Salsuginus thalkeni; $\mathrm{GS}=$ Gyrodactylus stableri $\mathrm{PM}-\mathrm{E}=$ Posthodiplostomum minimum in the eye; $\mathrm{PM}-\mathrm{BC}=P$. minimum in the body cavity. $r$ values higher than 0.097 (corrected) are significantly different from zero at $\alpha=0.05$.

extinct. These fluctuations affect river braidedness, habitat diversity, and populations of all aquatic invertebrates (Bentall, 1975; Knight et al., 1977).

Infrapopulation, sample prevalence, and mean correlations revealed no significant negative associations between species manifested as complementary infrapopulations (Table II), occurrence (prevalence, Table III), or average numbers of parasites per sample (means, Table IV). Statistically significant infrapopulation correlations between parasite species were only positive and occurred between the congeneric Gyrodactylus species, between $S$. thalkeni and eye $P$. minimum, and between the 2 ecotypes of $P$. minimum (Table II). Statistically significant prevalence and mean correlations were only positive, and occurred only between the 2 ecotypes of $P$. minimum (Tables III, IV). Statistically significant positive correlations between fish size and parasite species' infrapopulations were observed in the case of body surface monogeneans, Gyrodactylus stableri and Gyrodactylus bulbacanthus, and in the case of larval trematodes, in both host sexes when analyzed either together or separately (Table V). However, less than $10 \%$ of the variance in infrapopulation was explained by variance in host length for any of these parasites (calculate $r^{2}$ from Table V). The question of whether the mean was actually a function of prevalence was answered by calculating correlation coefficients between the 2

TABLE III. Between-parasite species prevalence correlations from 61 samples taken between 1982 and 1995.

\begin{tabular}{lcccccrr}
\hline $\begin{array}{l}\text { Parasite } \\
\text { species }\end{array}$ & MF* & TR & GB & ST & GS & PM-E & PM-BC \\
\hline MF & 1 & 0.35 & -0.04 & 0.26 & -0.01 & 0.28 & 0.30 \\
TR & & 1 & 0.04 & 0.31 & 0.43 & 0.08 & 0.11 \\
GB & & & 1 & 0.01 & 0.19 & -0.03 & -0.03 \\
ST & & & & 1 & 0.19 & 0.21 & 0.26 \\
GS & & & & & 1 & 0.16 & 0.19 \\
PM-E & & & & & 1 & 0.98 \\
PM-BC & & & & & & & 1 \\
\hline
\end{tabular}

* Abbreviations: MF = Myxobolus funduli; TR = Trichodina sp.; GB = Gyrodactylus bulbacanthus; $\mathrm{ST}=$ Salsuginus thalkeni $; \mathrm{GS}=$ Gyrodactylus stabler $\mathrm{PM}-\mathrm{E}=$ Posthodiplostomum minimum in the eye; $\mathrm{PM}-\mathrm{BC}=P$. minimum in the body cavity. $r$ values higher than 0.45 (corrected) are significantly different from zero at $\alpha=0.05$ 
TABLE IV. Between-parasite species mean correlations from 61 samples taken between 1982 and 1995 .

\begin{tabular}{lccccccc}
\hline $\begin{array}{c}\text { Parasite } \\
\text { species }\end{array}$ & MF* & TR & GB & ST & GS & PM-E & PM-BC \\
\hline MF & 1 & 0.08 & 0.02 & 0.19 & -0.10 & -0.15 & -0.07 \\
TR & & 1 & -0.04 & 0.19 & 0.16 & -0.02 & 0.08 \\
GB & & & 1 & 0.42 & -0.02 & 0.01 & 0.02 \\
ST & & & & 1 & 0.01 & 0.13 & 0.18 \\
GS & & & & & 1 & 0.19 & 0.23 \\
PM-E & & & & & 1 & 0.93 \\
PM-BC & & & & & & 1 \\
\hline
\end{tabular}

* Abbreviations: $\mathrm{MF}=$ Myxobolus funduli; $\mathrm{TR}=$ Trichodina $\mathrm{sp} . ; \mathrm{GB}=$ Gyrodactylus bulbacanthus; $\mathrm{ST}=$ Salsuginus thalkeni; $\mathrm{GS}=$ Gyrodactylus stableri; PM-E $=$ Posthodiplostomum minimum in the eye; $\mathrm{PM}-\mathrm{BC}=P$. minimum in the body cavity. $r$ values higher than 0.45 (corrected) are significantly different from zero at $\alpha=0.05$.

parameters for each parasite species. These coefficients ranged from 0.46 in the case of body cavity $P$. minimum, to 0.75 in the case of $G$. bulbacanthus, the latter being the only one in which at least half the variance in mean was explained by variance in prevalence. Gyrodactylus bulbacanthus was also the rarest of the parasites, and exhibited the least reaction to environmental fluctuations (Fig. 7; Tables VI, VIII).

Figures 4-10 show variations in the values of standard measures of parasite population structure (prevalence, mean, and variance/mean ratios) for the 7 different parasite species or ecotypes. There are 4 general patterns revealed by these data.

First, the generalist trematode $P$. minimum, as metacercariae in both eye and body cavity, exhibited major fluctuations in prevalence, mean, and aggregation, corresponding to changes in streamflow (Figs. 4, 5). The parasites became virtually extinct locally during the second and third high-water year, but extended periods of low water produced almost $100 \%$ infection, with relatively large numbers of parasites. The parasite population changes, however, lagged the annual streamflow changes by a year, and population descriptor values were correlated most

TABLE V. Correlations between host total length and parasite infrapopulations.

\begin{tabular}{lrrr}
\hline & \multicolumn{3}{c}{$r$ values } \\
\cline { 2 - 4 } Parasite & All fish & Females & \multicolumn{1}{c}{ Males } \\
\hline$n_{\text {MF* }}$ & 0.01 & 0.00 & 0.04 \\
TR & -0.04 & -0.07 & -0.02 \\
GB & 0.06 & 0.07 & 0.07 \\
ST & 0.04 & 0.01 & 0.06 \\
GS & 0.12 & 0.16 & 0.09 \\
PM-E & 0.26 & 0.19 & 0.30 \\
PM-BC & 0.20 & 0.11 & 0.26 \\
H'IA & -0.01 & 0.01 & 0.00 \\
SPD & 0.04 & 0.03 & 0.07 \\
\hline
\end{tabular}

* Abbreviations: $\mathrm{MF}=$ Myxobolus funduli; $\mathrm{TR}=$ Trichodina $\mathrm{sp} . ; \mathrm{GB}=$ Gyro dactylus bulbacanthus; $\mathrm{ST}=$ Salsuginus thalkeni $; \mathrm{GS}=$ Gyrodactylus stableri $\mathrm{PM}-\mathrm{E}=$ Posthodiplostomum minimum in the eye; $\mathrm{PM}-\mathrm{BC}=P$. minimum in the body cavity; H'IA = infradiversity; SPD = parasite species density for individual hosts. For all fish, $\mathrm{n}=1,219 ; r$ values higher than 0.056 are significantly different from zero at $\alpha=0.05$; for males, $\mathrm{n}=595, r$ values higher than 0.081 are significantly different from zero at $\alpha=0.05$; for females, $n=624, r$ values higher than 0.079 are significantly different from zero at $\alpha=0.05$.
TABLE VI. Order of abundance of the parasites of Fundulus zebrinus over a 14-yr period. Table entries are the rank order of the annual average number of parasites $(=[\Sigma($ mean $\times n)] /[$ number of collections in a given year]), by parasite species.

\begin{tabular}{cccccccc}
\hline Year & MF* & TR & GB & ST & GS & PM-E & PM-BC \\
\hline 1982 & 2 & 1 & 7 & 6 & 4 & 5 & 3 \\
1983 & 4 & 2 & 7 & 6 & 5 & 3 & 1 \\
1984 & 2 & 1 & 7 & 3 & 4 & 5 & 6 \\
1985 & 3 & 2 & 5 & 4 & 1 & 7 & 6 \\
1986 & 4 & 1 & 7 & 2 & 3 & 5 & 6 \\
1987 & 1 & 3 & 7 & 2 & 4 & 6 & 5 \\
1988 & 1 & 3 & 7 & 2 & 6 & 5 & 4 \\
1989 & 3 & 2 & 7 & 5 & 6 & 4 & 1 \\
1990 & 5 & 2 & 7 & 4 & 6 & 3 & 1 \\
1991 & 6 & 5 & 7 & 3 & 4 & 2 & 1 \\
1992 & 6 & 5 & 7 & 4 & 3 & 2 & 1 \\
1993 & 6 & 5 & 7 & 3 & 4 & 2 & 1 \\
1994 & 6 & 4 & 7 & 5 & 3 & 2 & 1 \\
1995 & 3 & 5 & 7 & 6 & 4 & 2 & 1 \\
\hline
\end{tabular}

* Abbreviations: MF = Myxobolus funduli; TR = Trichodina sp.; GB = Gyrodactylus bulbacanthus; $\mathrm{ST}=$ Salsuginus thalkeni; GS = Gyrodactylus stableri; PM-E $=$ Posthodiplostomum minimum in the eye; $\mathrm{PM}-\mathrm{BC}=P$. minimum in the body cavity.
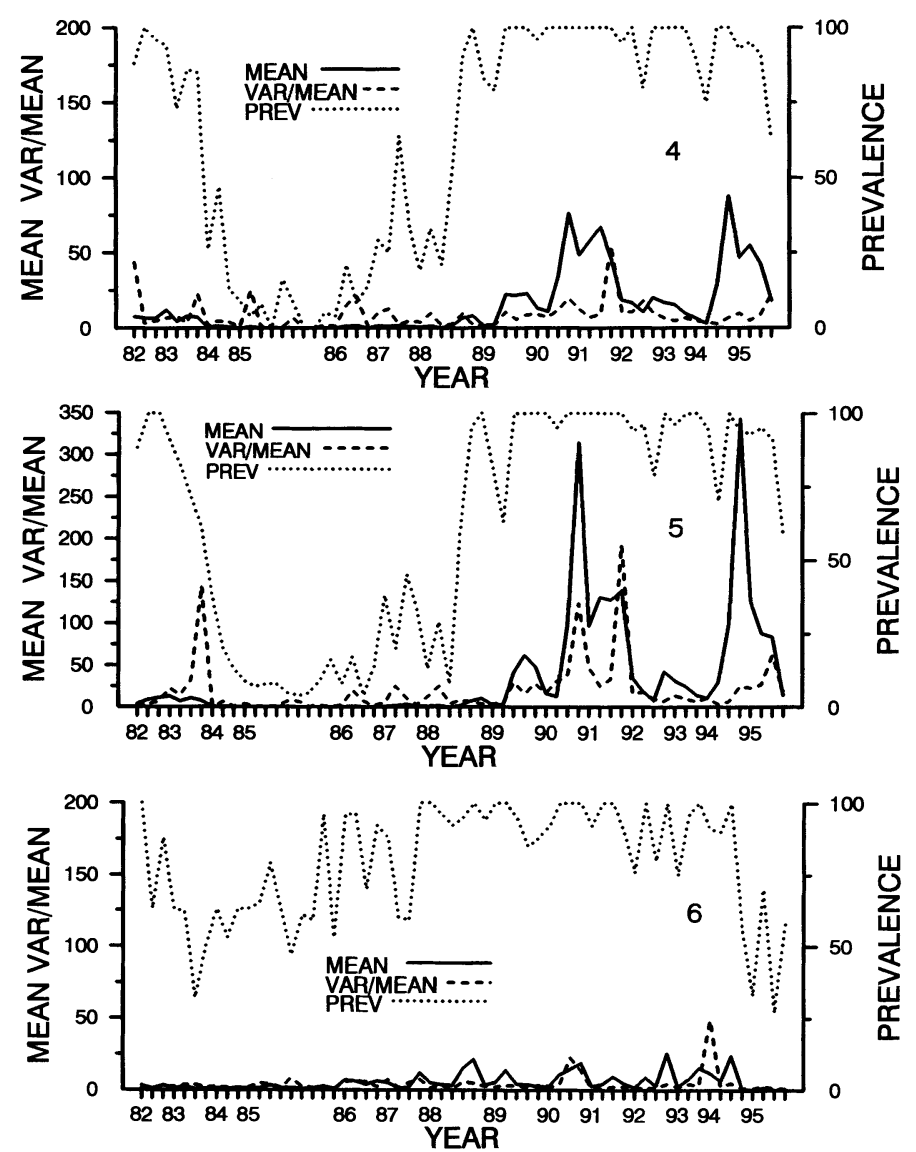

Figures 4-6. Population and community dynamics of parasites in Fundulus zebrinus for the period 1982-1995. 4. Prevalence, mean, and variance/mean ratios of eye-dwelling larval trematode Posthodiplostomum minimum. 5. Prevalence, mean, and variance/mean ratios of body cavity-dwelling larval trematode P. minimum. 6. Prevalence, mean, and variance/mean ratios of the gill monogene Salsuginus thalkeni. 

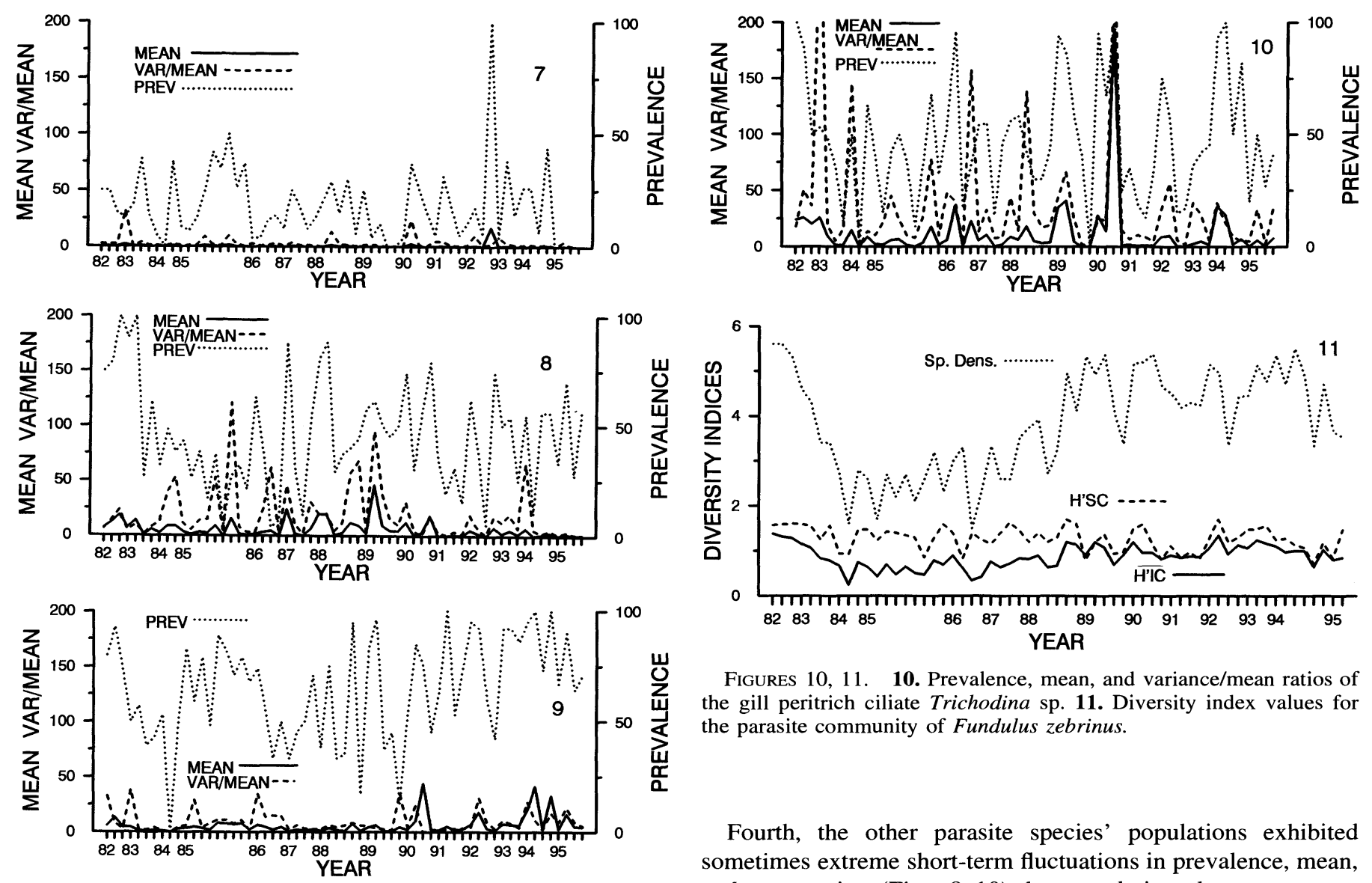

Figures 10,11 10. Prevalence, mean, and variance/mean ratios of the gill peritrich ciliate Trichodina sp. 11. Diversity index values for the parasite community of Fundulus zebrinus.

FiguRES 7-9. 7. Prevalence, mean, and variance/mean ratios of the gill monogenean Gyrodactylus bulbacanthus. 8. Prevalence, mean, and variance/mean ratios of the gill myxozoan Myxobolus funduli. 9. Prevalence, mean, and variance/mean ratios of the fin-dwelling monogenean Gyrodactylus stableri.

strongly with prior year's daily average flow rate (Tables VI, VII, VIII; Janovy and Hardin, 1988).

Second, the specialist monogenean $S$. thalkeni exhibited a relatively stable population structure, with high prevalence, low average numbers of parasites per host, and comparatively little aggregation (Fig. 6). Aside from a dampened response to the changing streamflow in 1982-1986, prevalence remained higher than $50 \%$ for the entire study, and the mean remained lower than 15 in all but 6 of the 61 samples.

Third, relatively rare species remained rare throughout the study period. The gill gyrodactylid ( $G$. bulbacanthus) infected an average of $18.9 \%$ of the population, with a mean of 0.70 parasites per fish (Fig. 7). In all years but one, G. bulbacanthus was the least abundant parasite (Table VI).

Fourth, the other parasite species' populations exhibited sometimes extreme short-term fluctuations in prevalence, mean, and aggregation (Figs. 8-10), but no obvious longer term responses to changing streamflow as did $P$. minimum, for example. Each species had a characteristic long-term population profile. Myxobolus funduli averaged fewer than 25 cysts per fish, but over the 14-yr period about half the fish were infected (Fig. 8); the body surface gyrodactylid (G. stableri) exhibited a similar pattern as that of $M$. funduli, but with higher prevalence (Fig. 9); and the gill peritrich ciliate Trichodina sp. exhibited the most extreme fluctuations of prevalence, mean, and aggregation (Fig. 10).

In the assessment of stability, the null hypothesis of no relationship between means and prevalences, and current year streamflow, prior year streamflow, or year of study was rejected in the case of Trichodina sp. (prevalence vs. current year streamflow only), $S$. thalkeni (all comparisons except prevalence vs. year of study), G. stableri (both mean and prevalence vs. year of study), and both ecotypes of $P$. minimum (Table VIII). However, in no case was more than half the variance in population parameters attributable to variance in year of study (calculated $r^{2}$ values from Table VIII), and except for the Pos-

TABLE VII. Correlations between annual streamflow and rank abundance for the parasites of Fundulus zebrinus, $1982-1995$

\begin{tabular}{|c|c|c|c|c|c|c|c|c|c|}
\hline & PWY* & CWY & MF & TR & GB & ST & GS & PM-E & PM-BC \\
\hline PWY & 1 & 0.39 & -0.44 & -0.52 & -0.64 & -0.47 & -0.54 & 0.70 & 0.88 \\
\hline CWY & & 1 & -0.21 & -0.26 & -0.28 & 0.29 & -0.25 & 0.18 & 0.28 \\
\hline
\end{tabular}

* Abbreviations: $\mathrm{PWY}=$ previous water year, $\mathrm{CWY}=$ current water year; $\mathrm{MF}=$ Myxobolus funduli TR $=$ Trichodina $\mathrm{sp} . ; \mathrm{GB}=$ Gyrodactylus bulbacanthus; $\mathrm{ST}=$ Salsuginus thalkeni; GS $=$ Gyrodactylus stableri PM-E $=$ Posthodiplostomum minimum in the eye; PM-BC $=P$. minimum in the body cavity. $r$ values higher than 0.514 are significantly different from zero at $\alpha=0.05$. 
TABLE VIII. Correlations between mean infrapopulation, prevalence (prev), current and prior year streamflows, and year of study, of parasites in Fundulus zebrinus from 61 samples taken between 1982 and 1995.

\begin{tabular}{|c|c|c|c|}
\hline \multirow{2}{*}{$\begin{array}{c}\text { Parasite } \\
\text { species }\end{array}$} & \multicolumn{3}{|c|}{$r$ values } \\
\hline & CWY & PRWY & YRSTDY \\
\hline \multicolumn{4}{|l|}{ MF* } \\
\hline Mean & -0.05 & -0.09 & -0.10 \\
\hline Prev & -0.07 & -0.34 & -0.15 \\
\hline \multicolumn{4}{|l|}{ TR } \\
\hline Mean & -0.18 & -0.13 & -0.01 \\
\hline Prev & -0.27 & -0.17 & 0.03 \\
\hline \multicolumn{4}{|l|}{ GB } \\
\hline Mean & -0.08 & -0.08 & 0.09 \\
\hline Prev & -0.06 & 0.07 & -0.04 \\
\hline \multicolumn{4}{|l|}{ ST } \\
\hline Mean & -0.46 & -0.27 & 0.32 \\
\hline Prev & -0.74 & -0.29 & 0.21 \\
\hline \multicolumn{4}{|l|}{ GS } \\
\hline Mean & -0.22 & -0.18 & 0.36 \\
\hline Prev & -0.31 & -0.21 & 0.35 \\
\hline \multicolumn{4}{|l|}{ PM-E } \\
\hline Mean & -0.24 & -0.50 & 0.58 \\
\hline Prev & -0.36 & -0.82 & 0.53 \\
\hline \multicolumn{4}{|l|}{ PM-BC } \\
\hline Mean & -0.25 & -0.37 & 0.47 \\
\hline Prev & -0.39 & -0.82 & 0.53 \\
\hline
\end{tabular}

* Abbreviations: MF = Myxobolus funduli; TR = Trichodina sp.; GB = Gyro dactylus bulbacanthus; $\mathrm{ST}=$ Salsuginus thalkeni; $\mathrm{GS}=$ Gyrodactylus stabler $;$ $\mathrm{PM}-\mathrm{E}=$ Posthodiplostomum minimum in the eye; $\mathrm{PM}-\mathrm{BC}=P$. minimum in the body cavity. Correlation between year of study and concurrent water year = -0.43 ; correlation between year of study and prior water year $=-0.52 . r$ values higher than 0.25 are significantly different from zero at $\alpha=0.05$.

thodiplostomum species, the highest fraction of attributable variance was less than $15 \%$.

At the infracommunity level, there was not a significant correlation between host size and infradiversity $\left(r=0.018 ; r_{\alpha=0.05}\right.$ $=0.056)$, but there was between host size and species density $(r=0.073)$. Periods of high streamflow altered the parasites' abundance ranks, and these changes were shown most strongly by the larval trematodes ( $P$. minimum) in both eye and body cavity (Table VI). Abundance ranks were also most strongly correlated with previous year streamflow (Table VII). Figure 11 shows species density, mean infracommunity diversity, and sample community diversity for the 14-yr study period, and Table IX gives correlations between these community descriptors and streamflow for current and previous water years. The drop in parasite species density during the early 1980 s corresponds to high water, and the slow "recovery" (rise) in species density corresponds to an extended period of decreasing flows. Prior statistical analysis showed these changes in population descriptor values to be negatively correlated with previous year's streamflow (Janovy and Hardin, 1988), and incorporation of the later $9 \mathrm{yr}$ of data did not change this observation (Table IX).

The difference between mean $\mathrm{H}^{\prime} \mathrm{IC}$ and $\mathrm{H}^{\prime} \mathrm{SC}$ is a difference between parasite community diversity in individual hosts and in the population of hosts (Janovy et al., 1992). In the present
TABLE IX. Correlations between annual streamflow, mean infracommunity diversity, sample community diversity, and species density for the parasites of Fundulus zebrinus, 1982-1995.

\begin{tabular}{lcccccr}
\hline & $\begin{array}{c}\text { Mean } \\
\text { H'IA }^{*}\end{array}$ & H'SA & $\begin{array}{c}\text { Species } \\
\text { density }\end{array}$ & $\begin{array}{c}\text { Mean } \\
\text { prev }\end{array}$ & PWY & CWY \\
\hline Mean H'IA & 1 & 0.41 & 0.88 & 0.87 & -0.68 & -0.39 \\
H'SA & & 1 & 0.12 & 0.12 & -0.02 & 0.05 \\
Species density & & & 1 & 0.96 & -0.76 & -0.52 \\
Mean prev & & & & 1 & -0.71 & -0.50 \\
PWY & & & & 1 & 0.39 \\
CWY & & & & & 1 \\
\hline
\end{tabular}

* Abbreviations: $\mathrm{PWY}=$ previous water year, $\mathrm{CWY}=$ current water year. $r$ values higher than 0.239 are significantly different from zero at $\alpha=0.05$.

study, this difference was greatest during high streamflow periods and tended to be reduced during low streamflow periods, e.g., the early 1990s (Fig. 11), but separate paired- $t$ analysis of high (1983-1988) water years, as well as low-water years (1982, 1989-1994), showed these differences to be significant at $\alpha=0.05$ (single-tailed test). Fifty-nine of the 61 collections exhibited species density distributions predicted by the multiple-kind lottery model of Janovy et al. (1995), i.e., fit the null model of no detectable interspecies associations regardless of source. Of the 2 that did not fit this model, 1 (18 August 1992) had more lightly infected fish than predicted and 1 (25 July 1983) had more heavily infected fish than predicted.

Between-year comparisons revealed potential mechanisms by which the larger population structure responses to changing streamflow were produced. For example, in the case of $P$. minimum, the parasite whose populations most strongly reacted to changes in transmission conditions, Figures 12 and 13 illustrate the annual recruitment events for 1990 and 1995, respectively. During extended periods of low water, snail intermediate host populations were high, parasite prevalence remained at virtually $100 \%$, and numbers of parasites per host increased by an order of magnitude (Fig. 12). During high-water events (Fig. 13), both prevalence and mean dropped, primarily because of failure of parasites to colonize new patches, possibly including youngof-the-year fish, especially in later collections. Mean fish lengths, in $\mathrm{cm}$ (var), for the 41995 collections were: 5.76 $(0.20), 6.68(0.90), 6.87(0.25)$, and $5.98(0.96)$, respectively (see above for dates). A 6-cm fish from the 4 August 1990 collection was scale-aged as a young-of-the-year. On that basis, fish from that collection were divided into first-year vs. secondand third-year fish, and mean total $P$. minimum infrapopulations (eye plus body cavity) were compared by means of $t$-tests on both raw and ranked infrapopulations. In both cases, the difference was significant at $\alpha=0.05$. The raw values for means (standard deviation, range) were: first year $=235.00(64.47$, 177-397); second-third year $=604.22(191.72,398-1,002)$. Mean total $P$. minimum infrapopulation (eye and body cavity) for the 16 May 1990 collections (all second-year fish prior to spawning) was 30.38 , and for the 5 October 1989 collection, 71.24. Except for P. minimum infections in the eyes, none of the other parasite populations exhibited these differences between years and collections within a year, but in the case of eye infections, total numbers of parasites were evidently limited 

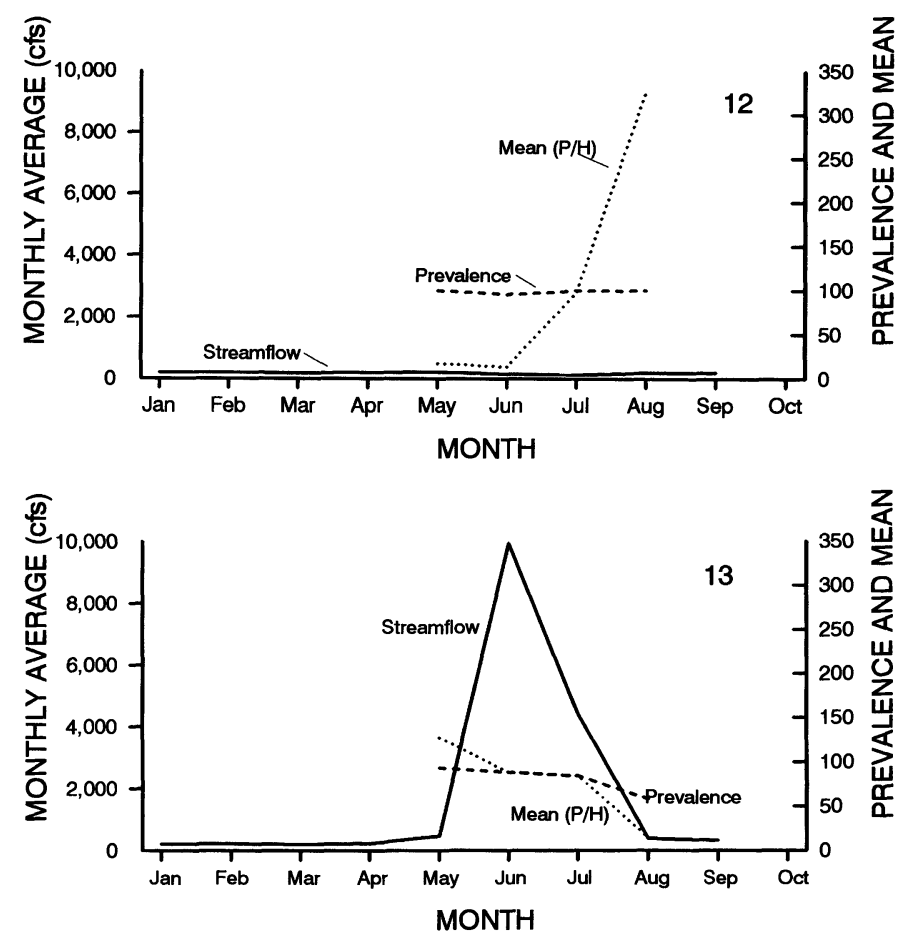

Figures 12, 13. Recruitment of Posthodiplostomum minimum into Fundulus zebrinus during the spring and summer of low- and highwater years. 12. Recruitment in 1990, a low-water year. Prevalence remained at $100 \%$ throughout the recruitment season, while parasites per fish increased an order of magnitude. 13. Recruitment in 1995, a highwater year. Both prevalence and parasites per fish dropped with the influx of young-of-the-year hosts.

and did not achieve the numbers equal to those in the body cavity.

In the case of all parasites except Trichodina sp., the mean number of parasites per host for the earliest collection of a field season (May) was significantly negatively correlated with the mean number of parasites per host in the latest collection of the previous year (Table $\mathrm{X}$ ).

\section{DISCUSSION}

The primary contribution of this study is the demonstration of parasite species differences in the long-term patterns of population descriptor values under highly variable transmission conditions. The sampling strategy provided a data set in which numbers for all parasite species were drawn from the same host samples, collected under conditions of maximum homogeneity possible in studies of natural parasite populations. Thus, the different long-term behaviors of mean, prevalence, and variance/mean ratios exhibited by $S$. thalkeni and $P$. minimum, respectively (Figs. 4-6), for example, are primarily a product of different reactions of evolved life cycle traits (species-specific transmission mechanisms) to a particular set of abiotic conditions, although those reactions are probably mediated by host biology, especially host reaction to high water. However, this is the first study of parasite population biology that links population structure to fixed life cycle traits, i.e., actually demonstrates an evolutionary component to differences in parasite
TABLE X. Correlations between mean parasites per host in first collection of a year and difference between that value and mean parasites per host for last collection of previous year, 1982-1995. $n=13$.

\begin{tabular}{lc}
\hline Parasite species & Correlation coefficients \\
\hline MF* & -0.633 \\
TR & -0.446 \\
GB & -0.990 \\
ST & -0.910 \\
GS & -0.858 \\
PM-E & -0.964 \\
PM-BC & -0.995 \\
\hline
\end{tabular}

* Abbreviations: $\mathrm{MF}=$ Myxobolus funduli $; \mathrm{TR}=$ Trichodina $\mathrm{sp} . ; \mathrm{GB}=$ Gyrodactylus bulbacanthus; $\mathrm{ST}=$ Salsuginus thalkeni $; \mathrm{GS}=$ Gyrodactylus stableri; $\mathrm{PM}-\mathrm{E}=$ Posthodiplostomum minimum in the eye; $\mathrm{PM}-\mathrm{BC}=P$. minimum in the body cavity. $r$ values higher than 0.532 are significantly different from zero at $\alpha=0.05$.

species' population structures in addition to the commonly assumed ecological causalities.

A second contribution is the demonstration that parasite population structures exhibited resilience in spite of order of magnitude changes in transmission conditions. This kind of dynamic behavior is especially obvious in Trichodina sp. Being a ciliate, Trichodina sp. presumably has a relatively short, direct life cycle, and it is entirely possible that transmission can occur so quickly, with single fish serving as the source, that even the effects of weekly or monthly streamflow fluctuations on this parasite cannot be detected by the methods available for study. There is virtually nothing in the literature concerning the life cycle and natural transmission of Trichodina spp., but $\mathrm{Li}$ and Desser (1983) showed experimentally that transmission could occur between heterologous hosts within 2 days, an observation consistent with the above interpretation of population dynamics.

At the community level, stability superimposed on short-term variation is the rule, with the general order of relative abundance, trematode metacercariae (high), and gill gyrodactylids (low) being maintained over the long term except during the perturbation of high streamflow. Following the perturbation, trematode larval position was regained when the relatively temporary (2-3 yr) perturbation of high water subsided.

Intuitively, one would expect the diversity of parasites in a host population to be higher than in host individuals (thus the choice of single-tailed paired- $t$ ). In the present study, this difference in diversity was both statistically significant and maintained over the long term, although the difference was much less during extended periods of low water than in high water periods. When compared, mean $\mathrm{H}^{\prime} \mathrm{IC}$ and $\mathrm{H}^{\prime} \mathrm{SC}$ actually reveal the extent to which the infection experience of an individual host matches that of the host population. Frequency distributions of parasites among hosts provide a measure of the difference between individual and host population infection experiences for single parasite species, namely the extent of aggregation. It is clear that transmission conditions can alter the extent to which infrapopulations are aggregated, thus the extent to which the experience of the individual is equivalent to that of the group (Janovy and Kutish, 1988). Similarly, one would expect the extent to which the mean infracommunity diversity (infection status of the individual host) equals the sample community diversity (infection status of the population) to be a 
function of transmission conditions. The present study is perhaps the only published data set that explicitly demonstrates the latter expectation being met.

Although a given set of abiotic conditions may affect 2 parasite species differently, such differences are primarily a function of the numbers, distributions, and natures of infective stages, which in turn are a product of evolved life cycles. For example, high streamflow affects $P$. minimum in 2 ways: (1) removes infective stages (swimming cercariae) from the environment by greatly reducing the numbers of snails present; and (2) drastically alters the physical conditions through which cercariae must swim to find a fish (Stables and Chappell, 1986; Webbe, 1966a, 1966b). Both of these effects and the resulting changes in parasite population structure can be predicted from a knowledge of strigeoid trematode life cycles (Yamaguti, 1975). The relative stability of $S$. thalkeni populations, however, is not so easy to predict from life cycle knowledge. In this case, the worms are long-lived and produce relatively few eggs that hatch into ciliated larvae that then must encounter a host directly. The best explanation for all 3 of the monogenean population dynamics patterns, as well as the positive associations revealed by infrapopulation and prevalence correlations (Tables II, III) between these worms and Trichodina sp. is that transmission occurs in a habitat selected by the host, perhaps a spawning habitat, that is available in some part of the river regardless of streamflow (Minckley and Klaassen, 1969; Brown, 1986; Schmeidler and Brown, 1990).

There is some evidence from the data that the parasites did have a negative impact on host populations. For example, if heavily parasitized fish survived the winter at the same rate as lightly parasitized fish, one would expect the correlation coefficients reported in Table $\mathrm{X}$ to be zero. All except that of Trichodina sp. are both negative and significantly different from zero, indicating heavily parasitized fish died more frequently than lightly infected fish, assuming both collections were random and from the same populations. The high correlations of both eye and body cavity $P$. minimum are of particular importance in this regard, because these are the only species studied that cannot be lost from the external surface. The cause of the fall-spring differences could be direct, e.g., inability of heavily parasitized fish to cope with winter stress, especially in low water years, or indirect, e.g., inability of heavily parasitized fish to avoid predators, especially fish-eating birds (the definitive hosts of $P$. minimum). This situation is virtually identical to that observed for bluegills by Lemly and Esch (1984a, 1984b), another study in which the character of the parasite, namely encysted trematodes, allowed such interpretation of the quantitative data. Although theoretical work predicts parasite population regulation by negative effects on heavily infected hosts (Anderson and May, 1978; Anderson and Gordon, 1982), in both the present study and that of Lemly and Esch (1984a, $1984 b)$ such regulation in natural populations was evidently only temporary, or annual, and over the long term was subordinate to the impact of abiotic conditions.

Thus the original questions have been answered. In this system, parasite population structure is relatively stable in some cases and responsive to abiotic changes in others, but in the latter case, these species are resilient and their populations attain preperturbance structure whenever transmission conditions return to their preperturbance state and remain relatively un- changed for a 2-3-yr period. The various species do respond differently to the fluctuating transmission conditions, and at least some of the community members, in this case the least abundant species, are relatively unresponsive to these fluctuations. The observations of species differences in responses to fluctuating streamflow are best interpreted as reflecting the species' different transmission mechanisms, which are in turn dictated by genetically controlled ontogenies, thus the conclusion that evolutionary constraints contribute to parasite population structure. These parasite species effects are seen even though the probable mediating influence of host habitat selection, especially during high water, is acknowledged. The transmission conditions in this system depend on streamflow, which in turn is a function of Rocky Mountain snowpack. Thus, there is also a logical connection between local parasite population and community structure and regional, if not global, weather patterns that ultimately produce the annual snowpack.

\section{ACKNOWLEDGMENTS}

The authors express their appreciation for use of facilities at the University of Nebraska's Cedar Point Biological Station, Keith County, Nebraska, for use of private property belonging to Darrell Thalken, and for seining help from a very long list of students and friends.

\section{LITERATURE CITED}

Anderson, R. M., AND D. M. Gordon. 1982. Processes influencing the distribution of parasite numbers within host populations with special emphasis on parasite-induced host mortalities. Parasitology 85: 373-398.

- AND R. M. MAY. 1978. Regulation and stability of host-parasite population interactions I. Regulatory processes. Journal of Animal Ecology 47: 219-247.

Bentall, R. (Preparator). 1975. Hydrology, Nebraska Mid-state Division, Pick-Sloan Missouri Basin Program, and associated areas UNL Conservation and Survey Division, Lincoln, Nebraska, 256 p.

Brown, K. L. 1986. Population demographic and genetic structure of plains killifish from the Kansas and Arkansas River basins in Kansas. Transactions of the American Fisheries Society 115: 568-576.

CAmp, J. W., AND H. W. Huizinga. 1980. Seasonal population interactions of Acanthocephalus dirus (Van Cleave 1931). Journal of Parasitology 66: 299-304.

Clopton, R. E., AND J. Janovy, JR. 1991. FieldStat. Hotel Intestine Software, Inc., Lincoln, Nebraska.

Dobson, A. P., AND S. W. PACAla. 1992. The parasites of Anolis lizards in the northern Lesser Antilles II. The structure of the parasite community. Oecologia 92: 118-125.

Esch, G. W., A. W. Shostak, D. J. Marcogliese, and T. M. Goater. 1990. Patterns and processes in helminth parasite communities: An overview. In Parasite communities: Patterns and processes, G. W. Esch, A. O. Bush, and J. M. Aho (eds.). Chapman and Hall, New York, New York, p. 1-19.

Granath, W. O., AND G. W. Esch. 1983a. Temperature and other factors that regulate the composition and infrapopulation densities of Bothriocephalus acheilognathi (Cestoda) in Gambusia affinis. Journal of Parasitology 69: 1116-1124.

, AND —. 1983b. Seasonal dynamics of Bothriocephalus acheilognathi in ambient and thermally altered areas of a North Carolina cooling reservoir. Proceedings of the Helminthological Society of Washington 50: 205-218.

Janovy, J. JR., R. E. Clopton, D. A. Clopton, S. D. Snyder, A. Efting, AND L. KREBS. 1995. Species density distributions as null models for ecologically significant interactions of parasite species in an assemblage. Ecological Modelling 77: 189-196. 
evolutionary influences in providing structure to parasite species assemblages. Journal of Parasitology 78: 630-640.

-, M. T. FerdiG, AND M. A. MCDowell. 1990. A model of dynamic behavior of a parasite species assemblage. Journal of Theoretical Biology 142: 517-529.

, AND E. L. HARDIN. 1987. Population dynamics of the parasites in Fundulus zebrinus in the Platte River of Nebraska. Journal of Parasitology 73: 689-696.

, AND - 1988. Diversity of the parasite assemblage of Fundulus zebrinus in the Platte River of Nebraska. Journal of Parasitology 74: 207-213.

— AND G. W. KuTISH. 1988. A model of encounters between host and parasite populations. Journal of Theoretical Biology 134: 391401.

Knight, S. A., J. Janovy, JR., AND W. L. Current. 1977. Myxosoma funduli Kudo 1918 (Protozoa: Myxosporida) in Fundulus kansae: Summer epizootiology. Journal of Parasitology 63: 897-902.

LEMLY, A. D., AND G. W. EsCH. 1984a. Population biology of the trematode $U$ vulifer ambloplitis (Hughes, 1927) in juvenile bluegill sunfish, Lepomis macrochirus, and largemouth bass, Micropterus salmoides. Journal of Parasitology 70: 466-474.

, AND - 1984b. Effects of the trematode Uvulifer ambloplitis on juvenile bluegill sunfish, Lepomis macrochirus: Ecological implications. Journal of Parasitology 70: 475-492.

LI, L., AND S. S. DESSER. 1983. Trichodina algonquinensis, a new species of peritrich ciliate from Ontario freshwater fish, and observations on its transmission. Canadian Journal of Zoology 61: 11591164.

Margolis, L., G. W. Esch, J. C. Holmes, A. M. Kuris, and G. A. SCHAD. 1982. The use of ecological terms in parasitology (report of an ad hoc committee of the American Society of Parasitologists). Journal of Parasitology 68: 131-133.

MiNCKLEY, C. O., AND H. E. KLAASSEN. 1969. Life history of the plains killifish, Fundulus kansae (Garman), in the Smoky Hill River, Kansas. Transactions of the American Fisheries Society 98: 460-465.

SChmeIdler, N. J., III, AND K. L. Brown. 1990. The importance of sampling scale in the assessment of intraspecific life-history differences in plains killifish, Fundulus zebrinus, populations (Pisces: Cyprinodontidae). Environmental Biology of Fishes 29: 263-275.

Silverton, J., AND J. B. Wilson. 1994. Community structure in a desert perennial community. Ecology 75: 409-417.

Stables, J. N., and L. H. Chappell. 1986. Diplostomum spathaceum (Rud. 1819): Effects of physical factors on the infection of rainbow trout (Salmo gairdneri) by cercariae. Parasitology 93: 71-79.

TAYloR, L. R., I. P. WoIWod, AND J. N. PERRY. 1978. The densitydependence of spatial behavior and the rarity of randomness. Journal of Animal Ecology 47: 383-406. , AND

1979. The negative binomial as a dynamic ecological model for aggregation and the density dependence of k. Journal of Animal Ecology 48: 289-304.

Webbe, G. 1966a. The effect of water velocities on the infection of animals exposed to Schistosoma mansoni cercariae. Annals of Tropical Medicine and Parasitology 60: 78-84.

WebBe, G. 1966b. The effect of water velocities on the infection of Biomphalaria sudanica tanganyicensis exposed to different numbers of Schistosoma mansoni miracidia. Annals of Tropical Medicine and Parasitology 60: 85-89.

YAMAGUTI, S. 1975. A synoptical review of life histories of digenetic trematodes of vertebrates. Keigaku Publishing Company, Tokyo, Japan, 590 p. 